\title{
Posso Ser Candidato a Presidente? Depende do STF
}

Antônio Rodolfo Franco Mota Veloso*

Martonio Mont'Alverne Barreto Lima**

1 Considerações iniciais. 2 Réu criminal pode ser candidato à Presidência da República? Eis a questão. 2.1 A gênese da dúvida. 2.2 Em busca da solução perdida: (não) pode um réu criminal ser, ao menos, candidato à Presidência da República? 3 Conclusão. Referências.

\section{RESUMO}

Analisa a (im)possibilidade de o Judiciário impedir a candidatura de uma pessoa que esteja sendo processada criminalmente em primeira instância ao cargo de Presidente da República. O estudo aufere relevância desde a análise da realidade político-jurídico-econômica nos governos Dilma $\left(2^{\circ}\right.$ mandato) e Temer, em que pode ser constatada a intensificação do casuísmo nas decisões proferidas pelo Supremo Tribunal Federal (STF), principalmente quando se verificam os argumentos expressos nos votos de alguns ministros, podendo ser constatados contrastes entre as decisões, ainda que os casos sejam semelhantes. Em decorrência desses dados, emergem indagações em relação à possibilidade de o Judiciário, com a aplicação de determinados princípios (mais especificamente da moralidade, da presunção de inocência e da legalidade), impedir a candidatura de uma pessoa à Presidência da República, conquanto não esteja essa hipótese de inelegibilidade disposta no ordenamento jurídico. Assim, este trabalho tem como objetivos estudar as decisões do STF que possam influenciar futuros pensamentos dos magistrados, bem como debater o modo como os princípios da moralidade, da legalidade e da presunção de inocência são aplicados a essa situação. Para alcançar tais finalidades, far-se-á um levantamento da legislação e de julgados do STF que tratem (in)diretamente da inelegibilidade para, no segundo momento, confrontá-las com os referidos princípios, concluindo que a atuação dos ministros do STF enseja preocupação em virtude da ausência de previsibilidade de suas decisões. Por isso, por mais que os autores entendam não ser possível a ampliação do rol de inelegíveis, senão por meio de lei complementar, as fundamentações expressas pelos membros da referida Corte dão base ao receio de que, com base na imprecisa moralidade, pessoas possam ser impedidas de se candidatar a um cargo público.

Palavras-chave: Inelegibilidade. Primeira Instância. Presidente da República. Supremo Tribunal Federal.

* Mestrando em Direito pela Universidade de Fortaleza (UNIFOR), com foco na área de concentração em Direito Constitucional Público e Teoria Política. Especialista em Direito Público (2014). Bacharel em Direito pela Faculdade Christus (2011). Professor de Direito Penal, Processo Penal e Direito Constitucional do Centro Universitário Christus (Unichristus). Editor-Assistente da Revista Opinião Jurídica (Qualis A2). E-mail: <rodolfo_fmv@hotmail.com>.https://orcid.org/0000-0002-1718-1595

** Professor Titular da Universidade de Fortaleza (UNIFOR) (Fortaleza, CE, Brasil). Doutor em Direito pela Joahann Wolfgang Goethe-Universität/Frankfurt am Main (Alemanha). Procurador do Município de Fortaleza. E-mail: <barreto@unifor.br>.https://orcid.org/0000-0003-0052-2901 


\section{CONSIDERAÇÕES INICIAIS}

As dificuldades institucionais do Brasil no atual momento (2017) se fortalecem quando temos como foco de análise a realidade político/jurídica brasileira, já que não existe - ou, pelo menos, há uma mitigação crescente - qualquer tipo de estabilidade ou de previsibilidade concernente à aplicação dos dispositivos do ordenamento jurídico e dos rumos da democracia. Tais dificuldades são oriundas do ceticismo, sempre crescente, em relação às funções dos Poderes (Executivo, Legislativo e Judiciário). Isso é justificável, pois os membros do Executivo e do Legislativo, ${ }^{1}$ constantemente, estão nos centros das atenções, seja pelo exercício de seu mister, seja em razão das incessantes acusações contra seus integrantes pela prática de crimes, promoções pessoais e/ou de familiares etc. ${ }^{2}$

Com esse problema institucional, gerou-se um vácuo a ser preenchido pelo Judiciário e pelo Ministério Público, ${ }^{3}$ os quais passaram a, cada vez mais, ter uma posição ativista, reivindicando os bastiões da Constituição Federal e da democracia. Ao trazer para si a agenda de "satisfazer os anseios da população", com suporte na justificativa de que o Texto Constitucional não pode ser engessado, devendo ser reconhecida sua mutabilidade (mutação constitucional) ${ }^{4}$ agentes constitucionais não eleitos delimitaram o espaço da política, especialmente pela criminalização dos agentes políticos (partidos etc.). Dessa maneira, os anseios sociais começaram a ser satisfeitos, ${ }^{5}$ independentemente das devidas e das necessárias modificações na legislação serem realizadas pelo poder legiferante. ${ }^{6-7}$

Esse raciocínio, em primeira análise, pode desembocar em uma insegurança jurídica, porquanto o Judiciário passa a interpretar o Texto Constitucional de acordo com as vicissitudes do caso que esteja analisando, ou seja, em situações excepcionais, serão utilizadas medidas extraordinárias, como defendido pelo desembargador federal da $4^{\text {a }}$ Região, Rômulo Pizzolatti. ${ }^{8}$ Tal panorama não traz nenhuma novidade. A dilatação do raio de alcance da burocracia judiciária, ante um poder político enfraquecido, apenas esconde os problemas graves de corrupção interna a essa burocracia e ainda coincide com o que já se sabe, pelo menos de modo mais preciso, desde a segunda metade do século XX, como bem demonstra o clássico estudo Behemot: "No centro da contrarrevolução encontrava-se o Judiciário. [...] Possivelmente, o Direito é a mais perniciosa de todas as armas nas lutas políticas, precisamente porque circunda os conceitos de direito e justiça" (NEUMANN, 2009, p. 20.). ${ }^{9}$

Desde o momento em que se passa a defender a flexibilização de normas constitucionais e infraconstitucionais, a fim de que haja uma adequação das variáveis dos casos excepcionais, pode-se, a título de hipótese, verificar que faltará previsibilidade da aplicação do ordenamento jurídico, pois, a depender do caso, das partes, do órgão julgador, do(s) magistrado(s) e do momento processual, as decisões poderão ou não se adequar aos precedentes firmados. Essa situação chega a ser grave, quando aspectos envolvendo políticos influentes são expostos à análise do Supremo Tribunal Federal, doravante STF, pois decisões paradoxais são proferidas pelos ministros da referida Corte, ainda que caso similar já tenha sido analisado pelo plenário, recentemente. ${ }^{10}$ 
Essa instabilidade nos julgamentos proferidos pelo STF, ensejando dúvidas relativas à aplicação das normas constitucionais e infraconstitucionais, conjugados às decisões proferidas na Ação Cautelar 4.070 e na Arguição de Descumprimento de Preceito Fundamental 402, casos responsáveis por produzir indagações, forçam-nos, como pesquisador, a fazer um levantamento das decisões proferidas pelo STF, bem como debater o modo como os princípios da moralidade, da legalidade e da presunção de inocência são aplicados a essa circunstância. Obviamente, este escrito não possui a petulância de trazer uma resposta categórica, mas de demonstrar um grave problema que existe e há de ser analisado com a imparcialidade que o mundo científico proporciona.

Apesar de, no primeiro momento, os casos serem similares, as peculiaridades deles têm de ser examinadas com bastante cautela, pois, em cada ação, para se alcançar o fim (impedir que os presidentes da Câmara dos Deputados e do Senado Federal, quando processados criminalmente, sejam destituídos desses cargos e não assumam a Presidência da República) utilizaram-se meios distintos (primeiro, o argumento foi baseado no processo penal; segundo, a base foi feita sobre questões envolvendo a moralidade que o cargo de chefe do Executivo nacional exige).

Com amparo no estudo dos referidos casos, surgem dúvidas em relação à possibilidade de alguém, ao responder ação criminal, poder disputar o cargo de Presidente da República. Essa discussão tem pertinência, em face da instabilidade na atualidade política brasileira, bem como em razão da falta de previsibilidade das decisões, cada vez mais casuísticas, do STF.

Para enfrentar essas dúvidas, devem-se adotar os referidos passos: 1) haver levantamento e análise da legislação e da jurisprudência, mormente o estudo das decisões proferidas pelos ministros do STF - obtidas com esteio no estudo dos votos escritos e orais disponibilizados pela referida Corte em seu sítio e em sua página no YouTube - na Ação Cautelar 4.070 e na Arguição de Descumprimento de Preceito Fundamental 402; 2) com a verticalização na legislação e na jurisprudência, realiza um exame a fim de verificar se aquela permite ou se é lacunosa ao tratar do objeto deste estudo (possibilidade de um réu em processo criminal ser candidato ao cargo de Presidente da República) e se o STF já tratou de evento similar, ou tentar identificar qual a tendência a partir da análise dos julgados; 3) com o confronto dessas posições, verificar se, por mais que a legislação e a jurisprudência nunca tenham enfrentado o tema, se referida hipótese é possível de ser aplicada.

O desenvolvimento será dividido em duas partes: a primeira analisa a Ação Cautelar 4.070 e a ADPF 402, responsáveis por ensejar dúvidas no tocante à possibilidade de uma pessoa, respondendo a processo criminal, ser impedida de se candidatar ao cargo de Presidente da República; a segunda parte faz um estudo da legislação, bem como uma análise filosófica, com o fito de descobrir se essa possibilidade existe e, caso não, se o Poder Judiciário pode criar esse obstáculo.

\section{RÉU CRIMINAL PODE SER CANDIDATO À PRESIDÊNCIA DA REPÚBLI- CA? EIS A QUESTÃO}

No decurso da história brasileira, pode-se verificar que o Poder Judiciário nem sempre atuou de modo que possibilitasse um elevado grau de previsibilidade na aplicação do ordenamento 
jurídico, ${ }^{11}$ pois seus órgãos, em diversos momentos, proferiram decisões que não observavam os precedentes firmados, criando-se um nível de instabilidade na aplicação do ordenamento jurídico. ${ }^{12}$

Essa ausência de aplicação dos precedentes ${ }^{13}$ e inovação no modo de aplicar o texto normativo permite que dúvidas sejam produzidas em relação ao que pode ocorrer quando aspectos sensíveis (como a possibilidade de um réu criminal ser impedido de se candidatar ao cargo de Presidente da República) forem discutidos. Tal indagação possui alçada relevância, principalmente quando se analisam os argumentos dispostos nas decisões proferidas pelos ministros do STF na AC 4.070 e na ADPF 402.

A priori, a resposta a essa pergunta parece ser negativa, porquanto a legislação não expressa vedação a isso. Na análise - no entanto - da atuação do STF e dos ministros que compõem a Corte, em decisões monocráticas, ${ }^{14}$ bem como em relação aos recentes acontecimentos na realidade jurídico/política brasileira, percebe-se que seria, no mínimo, imprudente fazer uma afirmação tão categórica, prescindindo de um cuidadoso estudo sobre o tema. Daí a necessidade de se debruçar, no primeiro momento, sobre os referidos casos, cujos argumentos mostrados podem impedir que determinadas pessoas se candidatem ao cargo de Presidente da República.

Na segunda ocasião, é procedida a análise da legislação em vistas a se entender se os argumentos esboçados pelos ministros possuem fundamento no ordenamento jurídico ou se eles estão julgando de acordo com sua vontade, utilizando a legislação apenas para legitimar a decisão. Para tanto, princípios como os de legalidade e da moralidade administrativa também serão estudados, porque o Judiciário poderá utilizá-los como fundamento para obstar um réu em processo criminal de se candidatar ao mais alto cargo do Executivo Federal.

\subsection{A GÊNESE DA DÚVIDA}

O ano de 2016 foi, sem dúvida, um teste para a Constituição Federal e, por conseguinte, para a democracia brasileira, devido a acontecimentos, como Impeachment, casos de corrupção envolvendo os principais membros dos Poderes Executivo e Legislativo, mudança nas diretrizes governamentais que ensejaram dúvidas acerca da possibilidade de sua aplicação, debate no TSE sobre a cassação da chapa vencedora na eleição de 2014. Com efeito, o STF, como guardião da Carta Maior, teve de ser acionado em vários momentos a fim de solucionar diversos questionamentos.

No rol de ocasiões em que o STF foi acionado, encontram-se a Ação Cautelar 4.070 e a ADPF 402, que, aparentemente, são situações semelhantes, mas que devem ser tratadas de acordo com suas especificidades, pois, apesar de visarem ao mesmo objetivo - não deixar que um réu criminal esteja como Presidente de qualquer uma das casas do Congresso Nacional, podendo assumir, ainda que temporariamente, a função de Presidente da República -, os argumentos utilizados são diversos.

A Ação Cautelar 4.070, formulada pelo Ministério Público Federal, como relatada no

voto do ex-ministro Teori Zavascki, tinha como objetivo o afastamento cautelar de Eduardo 
Consentino da Cunha "[...] do cargo de deputado federal e, por arrastamento, da função de Presidente da Câmara dos Deputados" ou afastá-lo, "pelo menos, da função de Presidente da Câmara dos Deputados" (BRASIL, 2017b, p. 8).

Para alcançar tal pretensão, o Ministério Público Federal estruturou seu raciocínio com base nas medidas cautelares diversas da prisão, dispostas no art. 319 do Código de Processo Penal, em particular, a prevista no inciso VI, o qual estabelece "[...] suspensão do exercício de função pública [...] quando houver justo receio de sua utilização para a prática de infrações penais." Dessa maneira, foi ajuizado o pedido para se evitar que Eduardo Cunha continuasse utilizando o cargo de Presidente da Câmara dos Deputados como mecanismo para praticar crimes, bem como para criar obstáculos para a adequada apuração dos fatos (BRASIL, 2017b, p. 12).

Ao analisar o pedido, o ex-ministro Teori Zavascki procurou demonstrar que a referida medida cautelar possui caráter provisório, não podendo haver uma confusão dela com o juízo de culpa, devendo sua aplicação ser feita desde o instante em que for verificada a "[...] existência de riscos que possam transcender a própria instância processual penal, sobretudo quanto estiver sob consideração o exercício de funções públicas relevantes" (BRASIL, 2017b, p. 13), preservando-se, assim, a "utilidade do processo" e a "finalidade do cargo público" (BRASIL, 2017b, p. 13).

Ademais, a possibilidade da aplicação da medida prevista no Diploma Processual Penal é possível em decorrência da inafastabilidade do Poder Judiciário (BRASIL, 2017b, p. 21), comparando-se com a possível suspensão do Presidente da República, conforme art. 86, § $1^{\circ}$, da Constituição Federal (BRASIL, 2017b, p. 25). Não se haveria de falar em violação ao princípio da separação dos Poderes: o mencionado caso não se encontra nas hipóteses, conforme imposição feita pela Constituição Federal, que só podem ser deliberadas pela Casa respectiva - perda do mandato por se enquadrar nas situações previstas nos incisos I, II e VI do art. 55 (art. 55, § 2 ${ }^{\circ}$, da Constituição Federal) e sustação do andamento de ação criminal contra senador ou deputado federal (art. 53, § $3^{\circ}$, da Constituição Federal) (BRASIL, 2017b, p. 14-15).

As explanações procedidas até aqui objetivam demonstrar que os referidos cargos não redundam em uma blindagem aos réus (BRASIL, 2017b, p. 26). Por isso, o ex-ministro Teori Zavascki deferiu, em sede de liminar, os pedidos feitos pelo Ministério Público, suspendendo Eduardo Consentino da Cunha do exercício do mandato de deputado federal e, por conseguinte, de Presidente da Câmara dos Deputados (BRASIL, 2017b, p. 73). Merece ser lembrado o fato de que essa decisão foi tomada cinco meses após o pedido inicial. É sobre este conjunto de fatos que recai a suspeita de o STF não responder convenientemente pela guarda da institucionalidade que lhe atribuiu a Carta Cidadã. Os setores políticos vinculados ao governo da então Presidente Dilma Rousseff afirmavam que a aceitação da denúncia por Eduardo Cunha contra a Presidente, por crime de responsabilidade, estava eivada de vício: era ele processado criminalmente, portanto não poderia ocupar o cargo de Presidente da 
Câmara dos Deputados; e a aceitação da denúncia deu-se apenas em razão de o partido da Presidente ter votado contra Eduardo Cunha na Comissão de Ética da Casa. A permanência de Eduardo Cunha até o afastamento da Presidente Dilma foi decisiva para o sucesso desse afastamento, quando da votação, em 17 de abril de 2017. Por essa razão, o fato de o STF ter deixasdo para julgar esse pedido contra Eduardo Cunha somente após essa data é um ponto ainda em aberto, a robustecer o argumento deste texto, isto é, a dificuldade do STF na manutenção da segurança constitucional.

Deve-se ressaltar a ideia de que, em virtude da excepcionalidade do caso, a decisão liminar proferida pelo ex-ministro Teori Zavascki foi encaminhada para o plenário para que pudesse ser referendada. Todos os ministros do STF acompanharam na integralidade o voto proferido pelo relator. Alguns, como a ministra Rosa Weber, limitaram-se a assegurar que acompanhavam o relator em sua integralidade; outros, o Ministro Gilmar Mendes, por exemplo, discorreram sobre a gravidade da contenda, demonstrando, com base em Peter Häberle, a incompletude das normas constitucionais.

A ADPF 402, ajuizada pela Rede de Sustentabilidade, tinha como objetivo fazer que o STF reconhecesse a "[...] impossibilidade de que pessoas que respondem ou venham a responder à ação penal instaurada pelo STF assumam ou ocupem cargos em cujas atribuições constitucionais figure a substituição do(a) Presidente da República" (BRASIL, 2016a, online), pois o cargo necessita ser "honrado", justificando o pedido de não deixar que um deputado federal ou um senador, que esteja sendo processado criminalmente por denúncia feita durante o seu mandato e recebida pelo STF, seja presidente de suas respectivas Casas. Esse raciocínio decorre do fato de esses cargos se encontrarem na linha sucessória à Presidência da República na hipótese de impedimento ou vacância, conforme art. 80 da Constituição Federal, o qual dispõe que "[...] em caso de impedimento do Presidente e do Vice-Presidente [da República], ou vacância dos respectivos cargos, serão sucessivamente chamados ao exercício da Presidência o Presidente da Câmara dos Deputados, o do Senado Federal e o do Supremo Tribunal Federal" (BRASIL, 1988, online).

Constata-se, portanto, não ser possível aplicar a substituição "por salto", ou seja, a Constituição Federal não permite que o Presidente do Senado Federal assuma a Presidência da República em virtude de o Presidente da Câmara dos Deputados, ainda que presente, ser réu em processo criminal no STF. Com esteio nesse raciocínio, conjugado com as diretrizes oriundas da separação dos Poderes (art. $2^{\circ}$ da CF), do princípio republicano (art. $1^{\circ}$ da CF) e da ordem estabelecida no art. 80 da CF, o autor solicita que o STF arquitete entendimento no sentido de obstruir a possibilidade de o membro do Legislativo Federal, enquadrado na situação de réu criminal na mais alta Corte, assumir a Presidência da respectiva Casa.

A análise de tal ação chegou a ser iniciada pelo STF, sendo suspensa em razão da urgência que o plenário tinha em referendar a decisão liminar proferida pelo ex-ministro Teori Zavascki na Ação Cautelar 4.070, como já exposto. A ADPF 402, contudo, voltou a lume quando, em dezembro de 2016, os advogados da Rede Sustentabilidade peticionaram 
a fim de reiterar solicitação de liminar disposta no tópico 55, item "b" da petição inicial. ${ }^{15}$ A repetição do pedido decorreu do fato de a mais alta Corte haver recebido parcialmente, em dezembro de 2016, denúncia contra o (até então) Presidente do Senado, Renan Calheiros, voltando à necessidade de o caso regressar à pauta do plenário do STF. ${ }^{16}$

O ministro Marco Aurélio, relator da ADPF 402, ao analisar o novo pedido em conjunto com os fatos novos expressos (recebimento da denúncia contra Renan Calheiros) e a decisão proferida pelo ex-ministro Teori Zavascki, em sede de pedido liminar, referendada pelo pleno do STF, decidiu "[...] afastar não do exercício do mandato de Senador, outorgado pelo povo alagoano, mas do cargo de Presidente do Senado o senador Renan Calheiros" (BRASIL, 2016c, p. 5-6).

Por causa da delicadeza da decisão proferida, o Relator decidiu submetê-la ao plenário, a fim de que houvesse análise por toda a Corte. Ressalta-se que esse evento trouxe diversos problemas, começando pelo fato de Renan Calheiros não aceitar a intimação para deixar o cargo de Presidente do Senado Federal.

O julgamento no plenário foi bastante peculiar: após a leitura do voto do Relator, o decano da Corte, Celso de Mello, solicitou aos pares exprimir seu voto antes dos demais membros, atitude insólita, pois o Decano, com exceção do Presidente do STF, deve ser o último a votar no plenário. $\mathrm{O}$ voto do ministro Celso de Mello exibiu as especificidades do caso e decidiu que o afastamento, em sede de pedido liminar, do Chefe do Poder Legislativo da União, sem qualquer tipo de defesa, é de enorme gravidade. Por isso, o Decano decidiu

[...] referendar apenas em parte, em menor extensão, a decisão ora em exame, consignando que os substitutos eventuais do Presidente da República [...], caso ostentem a posição de réus criminais perante esta Corte Suprema, ficarão unicamente impossibilitados de exercer o ofício de Presidente da República, embora conservem a titularidade funcional da chefia e direção de suas respectivas Casas. (BRASIL, 2016d, p. 11).

A decisão do ministro Celso de Mello foi acompanhada pela maioria dos membros da Suprema Corte, chegando à conclusão diversa da proferida na Ação Cautelar 4.070, pela qual, em situação semelhante, Eduardo Consentino da Cunha fora suspenso de suas funções de deputado federal e, por conseguinte, de Presidente da Câmara dos Deputados, com base nos arts. 282, § 6º e 319, ambos do Código de Processo Penal. Assim, o plenário, por maioria dos votos, entendeu que aqueles que estiverem nos cargos, em que uma das funções for assumir a Presidência da República no caso de vacância, não serão afastados do seu cargo, mas ficarão impossibilitados de assumir, ainda que temporariamente, o mais alto posto do Executivo Federal. Esse raciocínio, como foi exposto, vai de encontro ao que foi solicitado na petição inicial da ADPF 402.

Como se percebe, o STF, confirmando hipótese suscitada na introdução desta pesquisa, vem agindo casuisticamente, ao modificar o seu posicionamento a depender do assunto que esteja sob exame. Ademais, ficou claro o entendimento da referida Corte de que o cargo de Presidente da República deve ser honrado, não podendo qualquer um assumi-lo, mesmo 
estando no cargo a lhe outorgar acesso à linha de sucessão presidencial. Por isso, a dúvida paira: será que um réu em processo criminal, ainda que tenha sido condenado por um órgão não colegiado, pode ser candidato à Presidência da República, porquanto há um grande risco de vir a macular a honra desse cargo?

\subsection{EM BUSCA DA SOLUÇÃO PERDIDA: (NÃO) PODE UM RÉU CRIMINAL SER, AO MENOS, CANDIDATO À PRESIDÊNCIA DA REPÚBLICA?}

O Poder Judiciário, em especial o STF, está sistematicamente proferindo decisões discrepantes, ainda que os casos sejam similares. As causas para isso são diversas, podendo esse tipo de atuação ser justificado desde a ocasião em que se constatam lacunas na Lei Fundamental, "obrigando" a referida Corte - posicionada como baluarte da democracia, conquanto seus membros não tenham sido escolhidos democraticamente - a tomar medidas para proteger a Constituição, ainda que tais atos a violem, ou seja, os fins justificando os meios.

$\mathrm{O}$ problema fica sempre mais latente, à medida que o STF analisa hard cases. Isso, por si, já é uma demonstração de que a decisão a ser proferida pela citada Corte deverá ser constituída com bastante cautela. Deve-se frisar, entretanto, o mero fato de o caso ser complexo, ser insuficiente para uma análise adequada, pois, como demonstrado na introdução deste experimento acadêmico (vide nota de fim $\mathrm{n}^{\mathrm{o}}$ 6), o STF também considera o momento político, bem como as partes. Daí a dúvida em relação à (im) possibilidade de alguém vir a ser impedido de candidatura à Presidência da República, pois, como será delineado, a legislação é lacunosa, não fornecendo uma resposta.

O recurso à moralidade é frequente no âmbito do Poder Judiciário e não somente no STF. Desde 2014, no Brasil, a abstração do recurso à moralidade tem servido, principalmente, para dilatar a atuação da burocracia judiciária: Poder Judiciário, Ministério Público e Polícia, o que, repetidas vezes, conduz à histeria da moralidade, inclusive contra a legalidade, com sua relativização.

Ao analisar a Constituição Federal, percebe-se que, em diversos momentos, há uma preocupação relativamente aos direitos políticos (arts. 14 a 16 da CF), dispondo sobre pontos que cuidam da maneira de exercer a soberania popular (art. 14, I, II e III, da CF), alistamento eleitoral (art. 14, $\S \S 1^{\circ}$ e $2^{\circ}$, da CF), (in) elegibilidade (art. 14, $\S \S 3^{\circ}, 4^{\circ}, 7^{\circ}, 8^{\circ}$, da CF), cassação e suspensão dos direitos políticos (art. 15 da CF) e aplicação da lei eleitoral no tempo (art. 16 da CF). (BRASIL, 1988).

Comprova-se que o excesso de cuidado disposto nessa parte da Lei Fundamental é um meio de aliar o exercício da soberania popular, permitindo que todos manifestem vontades a determinados limites capazes de impedir que pessoas assumam cargos por meio dos quais a sociedade será representada. Por isso, a Constituição impõe a criação de lei complementar para dispor sobre outras situações de inelegibilidade "[...] a fim de proteger a probidade administrativa, a moralidade para o exercício do mandato", devendo ser considerada "[...] a vida pregressa do candidato" (art. 14, § 9º da Constituição Federal). (BRASIL, 1988, online). 
Reportando-se, especificamente, à Presidência da República, quando se analisa o capítulo II do título IV da Constituição Federal (Do Poder Executivo), observa-se que todas as seções dispõem sobre hipóteses envolvendo aspectos atrelados ao exercício do cargo de Presidente da República e de outros órgãos relacionados, como os ministérios, os conselhos da República e da Defesa Nacional. Portanto, referido capítulo não tem como objetivo cuidar de matérias que envolvam a fase pré-presidencial, ficando isso claro, ao se observar o art. 77 da Lei Fundamental,17 o qual dispõe sobre a eleição do Presidente e do Vice-Presidente da República.

Por mais que esses dispositivos tenham como finalidade regulamentar a atuação do Presidente da República, deve-se frisar que os citados excertos preveem a possibilidade do afastamento, ainda que temporariamente, daquele que ocupa referido cargo. Para tanto, é necessário que haja denúncia pela prática de infração penal comum ou de crime de responsabilidade, 18 devendo ser recebida por, no mínimo, dois terços da Câmara dos Deputados (art. 86, caput, da CF). Uma vez aceita por essa Casa do Congresso, será instaurado processo, que pode tramitar no STF (infrações penais comuns) ou no Senado Federal (crime de responsabilidade), ficando o Presidente afastado de suas funções por um prazo de até 180 dias, vindo a regressar ao cargo na hipótese de o processo não ter sido concluído.

Vê-se que, até o momento, a Constituição não dispôs sobre a possibilidade de alguém que esteja sendo processado criminalmente, sem condenação, seja impedido de se candidatar ao cargo de Presidente da República. Ainda resta, no entanto, a análise da Lei Complementar no 64/1990, consideravelmente alterada pela Lei Complementar 135/2010, conhecida como "Lei da Ficha Limpa", cujo objetivo é regulamentar as hipóteses de inelegibilidade, conforme o $\S 9^{\circ}$ do art. 14 da Constituição Federal.

Ao fazer um estudo verticalizado da referida legislação - cuja elaboração tem o objetivo de "[...] proteger a probidade administrativa, a moralidade para exercício de mandato considerada vida pregressa do candidato", complementando a Constituição Federal (BRASIL, 1988, online), ao trazer mais situações em que uma pessoa pode ficar inelegível - constata-se que não há a previsão da possibilidade de impedir a candidatura à Presidência da República de um réu em processo criminal. ${ }^{19} \mathrm{O}$ mais próximo dessa hipótese é o caso arrolado no art. 1, I, "e”, da LC 64/90, o qual dispõe que serão inelegíveis “[...] os que forem condenados, em decisão transitada em julgado ou proferida por órgão judicial colegiado, desde a condenação até o transcurso do prazo de 8 (oito) anos após o cumprimento da pena."

Assim, a legislação, em nenhuma passagem, impede a candidatura de alguém ao cargo de Presidente da República, ainda que seja réu em processo criminal, emergindo a dúvida sobre se essa omissão é uma falha da referida Lei Complementar ou uma expressa vontade do legislador em não incluir essa possibilidade. Surge a indagação relativa ao modo como o STF irá se portar em tal circunstância.

A Constituição Federal, no tocante à presunção de inocência (art. $5^{\circ}$, LVII), dispõe que a certeza da prática do delito só se dá desde o trânsito em julgado de sentença penal 
condenatória, após o uso de todos os procedimentos que visem a assegurar ao réu o exercício dos direitos e das garantias constitucionais. Essa premissa traz como conclusões a ideia de que o processo penal é um instrumento de proteção do réu, a fim de evitar abusos por parte do Estado (LOPES JR. 2016, p. 32), ${ }^{20}$ bem como a sanção só pode ser imposta ao condenado após a observância de todo o conjunto de procedimentos processuais. ${ }^{21}$

Não se pode, contudo, olvidar que referida norma é um princípio, não possuindo caráter absoluto, ou seja, sua aplicação não prevalecerá em todos os conflitos de que participe - embora, por ser um mandamento de otimização, deva ser "[...] realizado na maior medida possível diante das condições fáticas e jurídicas existentes" (SILVA, 2011, p. 50) -, devendo ser analisado caso a caso o seu âmbito de atuação. Novais (2010, p. 705) posiciona-se no sentido de que a função legiferante, com base na criação de atos normativos, pode estabelecer soluções para alguns conflitos principiológicos, mas é impossível o Legislativo prever todas as soluções para esses confrontos, pois, por mais que essa árdua tarefa seja tentada, a complexidade e a evolução da sociedade demonstrarão que a legislação sempre estará atrasada, necessitando de que o Judiciário participe na aplicação da norma com amparo na interpretação exarada da colisão principiológica.22

A presunção de inocência, portanto, poderá ser relativizada em determinadas situações, ainda que não haja trânsito em julgado. ${ }^{23}$ Por se tratar, entretanto, de um princípio cuja mitigação acarreta um intenso influxo na vida de uma pessoa - pois outros direitos, como o de ir e vir, poderão ser temporariamente tolhidos - deve-se buscar meios para blindá-los da arbitragem do Estado, garantindo segurança jurídica. O principal instrumento capaz de proteger tais direitos é a legalidade (art. $5^{\circ}, \mathrm{II}, \mathrm{CF}$ ), visto que é a tática encontrada para proteger liberdades individuais contra abusos estatais passíveis de decorrer dos modelos de Estado Absoluto (Machtstaat) ou do Estado de Polícia (Polizeistaat), opondo-se "[...] a qualquer tipo de poder autoritário e a toda tendência de exacerbação individualista e personalista dos governantes" (MENDES; VALE, 2013, p. 244).

Desse ponto deflui o motivo de a legislação dever ser a mais clara possível, a fim de reduzir a margem de interpretações que possam ser contrastantes, acarretando imprevisibilidade na aplicação do dispositivo. Isso, todavia, nem sempre ocorre, podendo ser constatado com o emprego da moralidade como critério definidor, isto é, se uma pessoa pode ou não postular a Presidência da República.

O princípio da moralidade definido na Constituição da República não pode ser compreendido como dado impreciso, em que a ideia pessoal do aplicador do Direito, isto é, do julgador, venha a prevalecer sobre a racionalidade do entendimento constitucional e também legal. ${ }^{24}$ Não há como se abandonar razões concretas de cada sociedade, explicitadas devidamente em cada caso e articuladas com a normatividade constitucional e infraconstitucional. Pode-se dizer que a exigência de tal parâmetro impessoal corresponde à prática da República e do Estado de Direito, ou seja, todos são iguais perante a lei. O que autoriza a exclusão do subjetivismo da moralidade, a não ser que venha ela acompanhada da demonstração concreta do que consiste? Se, pois, a pena 
privativa da liberdade foi estabelecida, deve o julgador acercar-se de a toda certeza possível para não cometer ilegalidades julgando conforme o seu entendimento ou de acordo com as próprias emoções, e não conforme a Constituição e as leis. Vem daí o consolidado pensamento de que a dúvida haverá de beneficiar o réu. Como inexiste, na legislação brasileira, uma definição objetiva de moralidade e do que seria sua inobservância concretamente operada por quem ocupa cargos na Administração Pública, não há como se esperar que a mais alta Corte de Justiça de qualquer sociedade aplique tal preceito para condenação à pena privativa de liberdade, decorrentemente, apenas, das preferências pessoais dos julgadores e de seus apelos emocionais. ${ }^{25}$

A discussão sobre o conceito de moral no concreto, bem como a procura por sua definição jurídico-constitucional, a ponto de se tornar vinculante, deve recair sobre o legislador: este não enfrentou o tema em suas discussões, de modo que não há razão para o Judiciário substituí-lo. Quais as consequências de tal omissão? Este é um problema da política partidária, das disputas inerentes a qualquer democracia, com seus distintos agentes políticos. A sociedade que os elege deverá desenvolver, ela própria, maturidade de atentar para aqueles que escolhe e renovar-lhes, ou não, os mandatos concedidos, para o caso de exigir dos eleitos uma posição em situações como estas.

Ante qualquer circunstância, esse é um desafio da política, não do Poder Judiciário, a quem compete a aplicação das leis. As escolhas políticas devem emanar de quem recebeu voto. Eis aqui umas das preciosas garantias democráticas dos juízes - estabilidade e vitaliciedade exatamente para não se imiscuírem em opções políticas de criação de leis e se distanciarem de tais debates, aceitando a decisão dos eleitos e submetendo-as, objetivamente, ao seu crivo quando do momento da concreta aplicação da Carta Magna e das leis, sem ultrapassagem dos limites impostos pelo legislador. Lenio Streck atenta para a incorporação da Moral pelo Direito, no âmbito da qual se pode operar o caráter de "transformação da sociedade", porém, segundo esse autor, é necessário que haja a incorporação pelo Direito. Em outras palavras, é preciso que o legislador aja como recomenda a prática democrática (STRECK, 2012, p. 229-230).

O recurso ao ainda não decidido pelo legislador, no âmbito da Teoria do Direito e da interpretação constitucional, não representa nenhuma novidade:

dilatação do conceito de interpretação em uma base de princípios do direito [...] possui um preço: a pergunta sobre como o juiz pode responder um problema jurídico quando a objetividade da leitura (Leseart) deriva para o questionável, o que conduz a uma dupla dificuldade. A insegurança metódica [...] e quanto pode um juiz distanciar-se do texto, sem usurpar o lugar do legislador (MÜLLER, 2007, p. 189).

É do mesmo Friedrich Müller a afirmação de que a

[...] concretização do direito no Estado Democrático de Direito deve empenhar-se para abandonar os 'credos' que se pautam em conclusões metodicamente precipitadas e trabalhar elementos da argumentação que possam ser concretamente, no sentido de racionalmente, examinados e discutidos no âmbito da ciência do direito, ou seja, que de um modo bastante específico constituam-se como elementos de relativa objetividade (MULLER, 2009, p. 120). 
Como se pode depreender, exigir racionalidade e objetividade de julgadores - com maior vigor dos integrantes das mais altas cortes - consiste em uma verdadeira reivindicação da democracia e da lógica democrática. Não sem razão, fortalece, novamente, Lenio Streck esta mesma posição, ao lutar, no curso de convincente tratado, pela racionalidade e pela objetividade da ação interpretativa: "Somente a situação concreta é que serve de parâmetro para resposta correta (adequada à Constituição)” (STRECK, 2012, p. 179).

Passa-se agora ao ponto posterior da breve reflexão sobre o acúmulo da filosofia da Modernidade em torno da moralidade e de seu papel na democracia.

Para Barry (1996, p. 77), é "um grande erro" supor que "[...] justiça como imparcialidade" pode ser concebida como um sistema moral autossuficiente. Se todos temos ideias diferentes, o desafio da justiça como imparcialidade é saber "como vivemos juntos". O referido desafio é enfrentado, ainda, pelo pensamento filosófico da Modernidade, do mesmo modo a abandonar o preceito da moral como elemento regulador da vida em comum na res publica.

Na filosofia de Baruch de Espinosa, encontram-se fundamentos à rejeição da abstrata moral e de seu caráter pernicioso no emprego da Constituição e das leis em uma sociedade que pode ser constituída por afetos, ou seja, por disposições individuais de convivência plural e tolerante. Surpreendentemente atual, a afirmação de que o "[...] sumo bem se vivencia coletivamente, o que permite a Spinoza, na Ética, que a alegria se experimenta não individualmente, na solidão, mas em companhia dos demais, na Cidade" (GUIMARAENS, 2010, p. 168), é reveladora do engano ao estabelecimento da moral à esfera pública, sem a decisão de todos da Cidade, sem a objetividade das leis fixas da razão.

Uma vez que o Supremo Tribunal Federal - como quase todas as cortes constitucionais da atualidade - desafia os limites da Constituição Federal, para o pensamento espinoseano, não há novidade alguma nisso. A potência da multidão é o poder constituinte, isto é, o desejo de constituir a cidade, e de, juntos, vivenciar os afetos, provenientes do uso racional das leis. Assim, a tentativa de ultrapassagem do poder soberano representa "impossibilidade física", porquanto inadmissível a ideia de que o Supremo Tribunal Federal (e também os Poderes Legislativo e Executivo) ultrapassem o poder soberano, ainda que, por suas decisões, remanesçam eventuais dúvidas quanto a esta intenção (ESPINOSA, 2009, p. 38).

Essa constatação decorre do fato de que ninguém deve ir além do poder da multitudo. Quando a ultrapassagem do poder da multidão alcança o mundo do concreto, opera-se, igualmente, o que Espinosa definiu como poder da revelação, e a primeira que abandona o cenário é a razão humana, pois somente esta é capaz de guiar as pessoas à convivência comum e pacífica. Para Espinosa, a revelação dos profetas em relação às Sagradas Escrituras e a seus acontecimentos nada mais traduzem do que a disputa de poder pelo qual estes lutavam no interior da cidade. Nos capítulos I, II e III, do Tratado Teológico-Político, Espinosa discorre sobre a "religião revelada", como obra dos profetas, portanto da Teologia, uma vez que está dissociada da razão. E quem faz da razão e da Filosofia servas da fé, com certeza, "ensandecerá” (ESPINOSA, 2003, p. 224). A revelação das Sagradas Escrituras é ditada pelos profetas 
com certeza profética, a qual "[...] não era, evidentemente, uma certeza matemática, mas apenas moral, conforme consta também na própria Escritura” (ESPINOSA, 2003, p. 34). A revelação dos profetas era detentora da certeza da moral, a qual variava de acordo com o sinal recebido e assimilado por eles, daí se conclui pela relativização e pela pessoalização das profecias e interpretação dos Textos Sagrados. Dessa maneira é que, para Espinosa, a Escritura ainda poderia conter uma leitura de acordo com a variação do espírito de cada profeta:

[...] se o profeta era alegre, revelavam-se-lhes as vitórias, a paz e tudo que é motivo de alegria para os homens; [...] se, pelo contrário, era ele macambúzio, revelavam-se-lhes guerras, os suplícios e todos os males. [...] se o profeta era requintado, requintado era também o seu estilo em que aprendia a mente de Deus; se, pelo contrário era confuso, aprendia-a confusamente; [...] se o profeta era um rústico, apareciam-lhe bois e vacas; se era, porém, um soldado, apareciam-lhe chefe e exércitos (ESPINOSA, 2003, p. 35-36).

Quanto à reivindicação de última instância, com a legitimidade de "errar por último" em todos os casos, ainda que resulte na ultrapassagem da potência da multidão como corpo político, qualquer corte constitucional atrai a condição de reveladora do Texto Constitucional, a depender da "certeza da moral" e do temperamento de seus integrantes, conforme lhe seja o caso enfrentado. Não precisa ir muito além para perceber, com Espinosa, que esse tipo de funcionamento institucional não somente não mantém a unidade do corpo da sociedade, como também afasta a possibilidade de leis a "que todos estejam sujeitos" (ESPINOSA, 2004, p. 54).

$O$ recurso à superioridade do Supremo Tribunal Federal no sistema constitucional brasileiro para se desvincular de suas decisões pretéritas e retomar a rota da moralidade, sem descrevê-la objetivamente e sem referendar esse uso pelas Constituição e pelas leis, aproxima o Tribunal de um papel de revelador da Constituição; lugar ocupado em uma democracia, como se exprimiu, pela potência da multidão. Ora, se um corpo múltiplo pensa melhor do que um corpo menor (CHAUÍ, 2003, p. 294), não resta dúvida sobre a superioridade da política e dos políticos perante os outros poderes da cidade, a conviverem no mesmo espaço, em que "[...] impossível tirar aos homens a liberdade de dizerem o que pensam" (ESPINOSA, 2003, p. 309). O "dizer o que os homens pensam" de Espinosa corresponde à plena liberdade de manifestação de que haverá de ser o poder soberano detentor, isto é, o povo. Não se pode sequer relativizar a ideia de que Espinosa é o filósofo radical da liberdade pré-iluminista: é que reside na liberdade a distância entre Espinosa e Hobbes. Se, em Hobbes, a liberdade teria um aspecto "negativo", em Espinosa, esta adquire todo o seu conteúdo "positivo".

Não se confunde o pensamento de Espinosa com idealismo: primeiramente, porque Espinosa nos oferece a política como o espaço em que o ser humano poderá conquistar a liberdade. Essa mesma política não estará pressuposta, nem cairá dos céus, tampouco advirá pela força das orações; mas será uma luta na vita civitatis. Não se pode esquecer de que a prática da jurisdição constitucional (e quem a exerce: se um tribunal ou o próprio parlamento) traduz-se em uma disputa política inerente a qualquer sociedade, bem como não há de se olvidar de 
que instituições, ao saírem de seu limite constitucional, somente a ele retornarão também por força da democrática política. Uma paixão, para Espinosa, somente poderá ser vencida por outra paixão; esta maior.

Em segundo lugar, Espinosa evidencia o convencimento de que bem e mal são noções concretas:

Quão longe, no entanto, estamos de poderem todos conduzir-se unicamente pela razão! Cada um deixa-se levar pelo seu bel-prazer e, a maioria das vezes, tem a mente a tal ponto inundada pela avareza, a glória, a inveja, o ódio etc., que não lhe fica o mínimo espaço para a razão. [...] ninguém está obrigado a respeitar os contratos, exceto se tiver a esperança de bem maior ou receio de um mal maior (ESPINOSA, 2003, p. 239).

A referida elaboração é expressa também no Tratado da Emenda do Intelecto, de 1662, quando o Filósofo constata que, com base na experiência (Experientia) do que ocorre na vida ordinária (vita frequenter) - vale dizer do concreto e do real - nada de bom ou mau (nihil neque boni neque mali in si habere) acontece, a não ser que venha a ser que o ânimo (animus afficeretur) seja movido pela mesma experiência (SPINOZA, 2008, p. 6). Na mesma Emenda do Intelecto, a ratificação da relativização do bem e do mal, conforme suas circunstâncias reais, em que uma mesma coisa pode ser qualificada de boa ou má, deixa-se confirmar. $\mathrm{O}$ norte a conferir prumo às formulações de Espinosa será a apreciação aguçada das complexas e diversas condições de sua localização nos pensamentos e nas sociedades humanas (adeo ut uma eademque res possiti dici bona et mala, secundu diversos respectos, eodem modo ac perfectum et imperfectum) (SPINOZA, 2008, p. 12).

É, porém, no Breve Tratado, de 1660, que o Capítulo X se reporta, explicitamente, do que são bem e mal, de sua relação de existência não com a natureza, mas com a razão humana, ou seja, com os entia ratione. Dessa maneira, a bondade de Pedro e a maldade de Judas não se encontram fora de Pedro e de Judas, respectivamente: “[...] o bem e o mal não são coisas nem ações que existam na Natureza” (ESPINOSA, 2012, p. 87). É com tal firmeza que Espinosa atribui materialidade ao seu sistema filosófico para a defesa da liberdade e da segurança de todos com base na lei fixa a "[...] congregar as forças de todos para formar como que um só corpo, o corpo da sociedade" (ESPINOSA, 2003, p. 53). Demais disso, com a rejeição da ética de Espinosa a qualquer qualificação "moral do bem e do mal", inaugura-se uma preciosa distinção para a democracia e para a tolerância, a qual deve ser aplicada necessariamente por quem decide os destinos dos outros, ou seja, os juízes. A distinção mencionada consiste na concepção ética "[...] fundada na imanência dos modos de vida”, a qual se distingue "[...] de uma percepção moral, que se estrutura sobre uma perspectiva transcendente de valores" (GUIMARAES, 2010, p. 168). Não há como perceber rastro do pensamento idealista que se seguirá na Filosofia de Espinosa.

Ora, uma das principais marcas de Espinosa consiste naquela em que a natureza automovimenta-se (sic) e cria-se a si mesma (ISRAEL, 2009, p. 1998); e o ser humano, com sua razão, é dela apenas parte finita, influenciado e influenciador de suas ações, que não devem 
causar surpresa, tampouco desencanto, pois exigem para a sua adequada e livre compreensão a fria contemplação guiada pela razão produzida com liberdade de pensar, longe das pressões religiosas e dos poderosos.

Distante da certeza da moral e de todas as fáceis certezas não apreendidas pela liberdade da razão, deve a Constituição da República ser analisada sem, consequentemente, correr o risco de ser disputada e dilacerada pelo próprio corpo social que se propôs reger. Ao contrário: livre das amarras metafísicas, o Texto Normativo poderá pacificar qualquer sociedade na certeza de sua aplicação a todos, em quaisquer circunstâncias. Entende-se essa pacificação como a satisfação - a hilaritas de Espinosa - decorrente do afeto da alegria de se ter, em sociedade, a vida regrada da mesma maneira para todos.

Além de sua primeira dimensão pessoalista e religiosa, para Espinosa,

[...] a ordem moral nasce no intervalo cavado entre a recusa da ordem da vida comum e o desconhecimento da ordem da natureza, intervalo que, como insistirá a Ética, tende a ser preenchido pelo discurso normativo do moralista e do teólogo, que imaginam o homem fora da ordem natural (CHAUí, 2000, p. 572).

Percebe-se que o encadeamento entre Moral e Religião, aqui recusado com base na filosofia espinoseana, não apenas fica comprovado em julgados judiciais, como, para depois de sua constatação, implica a fragilidade de argumentação jurídica desenvolvida nessa base, exatamente por afastar os elementos objetivos do concreto.

Deve se insistir sobre a imposição da objetividade e da concretude da legislação constitucional e infraconstitucional a autorizarem e a legitimarem o uso do apelo moral e da aplicação para penas privativas de liberdade. A citação imediatamente anterior resume a formulação de Espinosa, a confirmar que, desde o século XVII, a Moral já não se encontrava em lugar de prestígio perante as pretensões de democracia e de justiça da Modernidade.

No seu Tractatus de Intellectus Emendatione, Espinosa parte rumo a uma ambiciosa tarefa: desmistificar a ordem das ideias, então libertadas da confusão entre o conhecido e o desconhecido (SPINOZA, 2008, p. 44). Buscando ser claro e preciso, afirma o Filósofo que a procura deverá sempre ter por base as coisas físicas ou os seres reais (entibus realibus) (SPINOZA, 2008, p. 74), a fim de que não se vitime pela desordem do pensamento, desordem que

[...] é responsável pela confusão entre o que está na imaginação e o que está no intelecto, "um sonhar de olhos abertos", que leva a que se comece com abstrações que confundem axiomas verdadeiros e "pervertem a ordem da natureza" (§ 75), colocando universais abstratos no lugar dos princípios ou da "fonte e origem da Natureza" (CHAUÍ, 2000, p. 576).

Veem-se como causas imanentes da desordem a abstração e o uso do intelecto para o olhar de fora da realidade, destituídos de seus nexos com a complexidade do real, suas causas e seus efeitos. Ao aproximar-se dessa visão abstrata sobre o princípio da moralidade, como escrito na Constituição Federal, as constantes manifestações dos integrantes da Corte incorrem no olhar externo aos entibus realibus, ou, com outras palavras, deixam de captar a complexidade em que se localiza o termo, por exemplo, o fato de não estar o princípio da 
moralidade, até hoje, regulamentado em todo seu potencial alcance social que poderia ter, e que a supressão desta lacuna deve emanar de quem é legitimado para as escolhas políticas. Quando não está esclarecida essa premissa de realidade, a consequência será também o próprio desvirtuamento da política democrática e, no caso brasileiro, de uma Constituição estatuída pela soberana multitudo, reunida em assembleia constituinte, composta de muitos e reunida para esse fim.

Aqui se encontram meios que o pensamento filosófico e laico do "radical iluminismo" assenta ao constitucionalismo e que, por serem de árduas conquistas da razão e da liberdade, não podem ser relativizadas em momento algum da vita civitatis da nação.

O afastamento da multitudo das instituições políticas e sociais corresponde ao fortalecimento dos temperamentos (ingenium) individuais. Para Espinosa, essa verdadeira tragédia desaguaria na ruptura do conatus, esforço construtor da sociedade e do Estado em coletividade, como também deixou a mesma lição Maquiavel. Por isso é que "[...] cabe às instituições frear a tendência antipolítica do ingenium individual, reforçando sua tendência à construção da sociedade comum." (GUIMARAES, 2010, p. 188).

mencionado conjunto de argumentação encontra guarida no que o pensamento constitucional pátrio possui de mais avançado e livre dos truques do voluntarismo da moral. Recorre-se, novamente, às palavras de Lenio Streck, para quem

[...] d) Direito não é moral. Direito não é sociologia. Direito é um conceito interpretativo e é aquilo que é emanado pelas instituições jurídicas, sendo que as questões e ele relativas encontram, necessariamente, respostas nas leis, nos princípios constitucionais, nos regulamentos e nos precedentes que tenham DNA constitucional, e não na vontade individual do aplicador. Ou seja, ele possui, sim, elementos (fortes) decorrentes de análises sociológicas, morais, etc. Só que estas, depois que o direito está posto - nesta nova perspectiva (paradigma do EDD) - não podem vir a corrigi-lo; e) É verdade que o direito presta legitimidade à política, compreendida como poder administrativo, sendo que a política the garante coercitividade. Concebendo a política como comunidade (polity), o direito faz parte dela. Compreendida como exercício da política (politics), há uma complicação entre eles na constituição do político. Como ponto de vista partidário, o direito tem o papel de limitar a política em prol dos direitos das minorias, definindo o limite das decisões contra-majoritárias. $\mathrm{O}$ direito é essencialmente político se o considerarmos como um empreendimento público. Daí política ou político, no sentido daquilo que é da polis, é sinônimo de público, de res publica (STRECK, 2013, p. 180).

Este é ainda um desafio em aberto a ser realizado pela sociedade política brasileira e não por um agente político institucional de maneira isolada, e, por boas razões, as tarefas de consolidação da democracia e de valorização do Documento Constitucional escrito por todos na esperança de ser atuante para todos, não serão responsabilidade de apenas um setor da sociedade.

Reporta-se a uma responsabilidade que poderá produzir o afeto da alegria; este exatamente ensejado pela passagem de um bem menor a um bem maior. Com efeito, 
os vícios sociais “[...] não se vinculam à má índole dos indivíduos, nem a virtude pela construção de uma consciência moral superior"; ao contrário, repousam nas instituições políticas, capazes de dotar suas atribuições na "[...] fundação institucional da liberdade a voltar-se 'contra o voluntarismo moralista que pressupõe a necessidade de difusão de virtudes morais universais"” (GUIMARAENS, 2010, p. 191). Eis, portanto, o desafio constitucional ainda por ser enfrentado. Para esse enfrentamento, deve-se contar, sobretudo, com a coragem cívica de todos e de suas instituições; com a coragem, enfim, de quem está disposto a enfrentar os vícios, a maldade e a parcialidade das falsas liberdades, sempre tão tentadoras aos que desejam o império do medo e da submissão da razão livre.

\section{CONCLUSÃO}

Este trabalho se propôs a verificar a possibilidade de uma pessoa ser impedida de se candidatar ao cargo de Presidente da República pelo fato de ter sido condenada criminalmente em primeira instância. Tal indagação surgiu da análise dos argumentos sustentados pelo Ministério Público, na Ação Cautelar 4.070, e pela Rede de Sustentabilidade, na ADPF 402. A despeito de utilizarem arrazoamentos distintos, os dois casos tinham o mesmo fim: impedir que um congressista, o qual estivesse sendo processado criminalmente, por força dos princípios da separação dos Poderes (art. $\left.2^{\circ}, \mathrm{CF}\right)$, do princípio republicano $\left(\operatorname{art} .1^{\circ}\right.$ da $\mathrm{CF}$ ), da moralidade exigida constitucionalmente para o exercício do mandato eletivo (art. $14, \S 9^{\circ}, \mathrm{CF}$ ) e da possibilidade de afastamento cautelar (art. 319, CPP), viesse a assumir, ainda que interinamente, a Presidência de sua respectiva Casa, visto que, conforme art. 80 da CF, havendo "[...] impedimento do Presidente e do Vice-Presidente, ou vacância dos respectivos cargos, serão sucessivamente chamados ao exercício da Presidência o Presidente da Câmara dos Deputados, o do Senado Federal e o do Supremo Tribunal Federal." (BRASIL, 1988, online).

Obviamente, resolveu-se ir além, indagando o seguinte: se uma pessoa, condenada criminalmente, resolver se candidatar ao cargo de Presidente da República, poderá o Judiciário, com base na ideia da moralidade que o cargo exige (art. 14, § 9, $\mathrm{CF}$ ), impedir o registro de sua candidatura?

Para que a resposta a tal indagação pudesse ser buscada, os argumentos oferecidos pelos ministros do STF na AC 4.070 e na ADPF 402 foram analisados, verificando-se que houve inconstância nos votos proferidos, demonstrando casuísmo. Isso dá azo ao receio de que a possibilidade de que é viável impedir referida candidatura, com suporte na ampliação do rol de inelegíveis, ainda que não pela via da lei complementar, com base na moralidade que o cargo exige do candidato.

Ao se demandar, contudo, o conceito da moralidade exigida pela Constituição, constatou-se, com esteio em um estudo de cunho filosófico, que o constituinte cometeu um erro ao trazer referida exigência sem traçar parâmetros objetivos, principalmente quando sua 
análise é feita com a presunção de inocência e com a legalidade. Isso é temerário, pois, como também foi demonstrado, há intensa oscilação das decisões proferidas pelos magistrados, a depender das vicissitudes do caso em análise.

Por isso, conclui-se que existem subterfúgios argumentativos que podem ser utilizados para a ampliação do rol de inelegíveis pelo Judiciário, isto é, uma pessoa pode ser inelegível ainda que não se enquadre em texto legal restritivo, como determina a Constituição, mas em virtude do entendimento do julgador. Isso merece ser criticado e combatido, porque fazer uso de elementos que não possuem conceito adequadamente claro, como moralidade, produz insegurança jurídica.

\title{
CAN I BE A CANDIDATE FOR PRESIDENT? IT DEPENDS ON THE STF
}

\begin{abstract}
It analyzes the (im)possibility of the Judiciary to prevent the candidacy of a person who is being criminally prosecuted in the first instance to the position of President of the Republic. The study is relevant since the analysis of the political-juridical-economic reality in the Dilma (2nd term) and Temer governments, in which it can be verified the intensification of casuism in the decisions made by the Supreme Federal Court (STF), especially when the arguments expressed in the votes of some ministers are verified, and contrasts can be seen among their decisions, even though the cases are similar. As a result of this data, questions arise regarding the possibility of the Judiciary, with the application of certain principles (more specifically: morality, presumption of innocence and legality), to prevent the candidacy of a person to the Presidency of the Republic, although this ineligibility hypothesis is not established in the legal system. Thus, this work aims to study the decisions of the Supreme Court that may influence future thoughts of the magistrates, as well as to discuss how the principles of morality, legality and presumption of innocence are applied to this situation. In order to achieve these objectives, we will gather legislation and judgments of the Supreme Court that deal (in) directly with the ineligibility and, in the second moment, confront them with the aforesaid principles, concluding that the actions of the STF ministers cause concern due to the lack of predictability of their decisions. Therefore, although the authors understand that it is not possible to expand the list of ineligible people other than by means of a complementary law, the grounds expressed by the members of the aforesaid Court give a foundation to the fear that, based on the imprecise morality, people can be prevented from applying for a public office.
\end{abstract}

Keywords: Ineligibility. First Instance. President of the Republic. Supreme Federal Court. 


\section{¿PUEDO SER CANDIDATO A PRESIDENTE? DEPENDE DEL STF}

\section{RESUMEN}

Analiza la (im)posibilidad de que el Poder Judicial impida la candidatura de una persona que esté siendo procesada criminalmente en primera instancia al cargo de Presidente de la República. El estudio aporta relevancia desde el análisis de la realidad político-jurídicoeconómica en los gobiernos Dilma ( $2^{\circ}$ mandato) y Temer, en que puede ser constatada la intensificación del casuismo en las decisiones dictadas por el Supremo Tribunal Federal (STF), principalmente cuando se verifican los argumentos expresados en los votos de algunos ministros, pudiendo constatarse contrastes entre las decisiones, aunque los casos sean similares. En consecuencia de estos datos, emergen indagaciones en relación a la posibilidad de que el Poder Judicial, con la aplicación de determinados principios (más específicamente de la moralidad, de la presunción de inocencia y de la legalidad) de impedir la candidatura de una persona a la Presidencia de la República, aunque no esté esta hipótesis de inelegibilidad dispuesta en el ordenamiento jurídico. Por lo tanto, este trabajo tiene como objetivos estudiar las decisiones del STF que puedan influir en futuros pensamientos de los magistrados, así como de debatir el modo en que los principios de la moralidad, la legalidad y la presunción de inocencia se aplican a esta situación. Para alcanzar tales fines, se procederá al levantamiento de la legislación y de juzgados del STF que traten (in) directamente la inelegibilidad para, en el segundo momento, confrontarlas con los referidos principios, concluyendo que la actuación de los ministros del STF plantea preocupación en virtud de la ausencia de previsibilidad de sus decisiones. Por eso, por más que los autores entiendan no ser posible la ampliación del rol de inelegibles, sino por medio de una ley complementaria, las fundamentaciones expresadas por los miembros de dicha Corte fundamentan el temor de que, con base en la imprecisa moralidad, las personas puedan ser impedidas de solicitar un cargo público.

Palabras clave: Inelegibilidad. Primera Instancia. Presidente de la República. Supremo Tribunal Federal.

1 Sabe-se que o Executivo, o Legislativo e o Judiciário de todos os entes da Federação possuem diversos problemas, mormente os vinculados às promoções daqueles que estão no círculo de influência. Para atender, contudo, a fins metodológicos de uma pesquisa científica, é necessário ressaltar que este trabalho tem como foco o Executivo e o Legislativo Federal para demonstrar o crescente poder do Judiciário e do Ministério Público.

2 Recentemente, tornou-se pública a lista dos políticos investigados pela suposta prática dos crimes de corrupção passiva, corrupção ativa, lavagem de dinheiro, falsidade ideológica; e há também descrições da formação de cartel e fraude em licitações. A situação é tão grave que nela estão nove ministros do governo Michel Temer, 29 senadores e 42 deputados federais. Referido rol pode ser acessado por meio de: (LISTA..., 2017).

3 Apesar do vácuo gerado pelo Executivo e pelo Legislativo em virtude de seus atos que vão de encontro aos anseios populares, deve-se frisar as indagações e as preocupações ventiladas por Martonio Mont'Alverne Barreto Lima, Paulo Roberto Clementino Queiroz e Valter Moura do Carmo, consoante as quais "[...] parece 
extremamente perigosa a visão messiânica do Judiciário. Acaso não se encontram em seu seio os mesmos problemas encontrados no fragilizado Legislativo? Não há corrupção no Judiciário? Não há favorecimentos? Uma diferença importante, entretanto, pode ser apontada nessa comparação: o funcionamento do Judiciário ainda é transparente, não é acompanhado pela imprensa com a mesma avidez que as ações nos parlamentos. Certo que existem exceções, como a transmissão televisiva e radiofônica, em tempo real, das sessões do pleno do Supremo Tribunal Federal. Porém, nem de longe se compara tal transparência ao cotidiano noticioso do País e do mundo que não trata do que ocorre no Judiciário, relativamente às suas disputas internas, ao seu orçamento e à sua execução." (LIMA; QUEIROZ; CARMO, 2016, p. 161.)

4 A título de ilustração, mencionam-se dois casos em que houve mutação constitucional para adequar, nas palavras do ministro do Supremo Tribunal Federal, Luís Roberto Barroso, a teoria à realidade: 1) alteração do entendimento, consolidado desde 2009, de que só pode haver a execução da pena a partir do trânsito em julgado de sentença penal condenatória. Essa modificação de posicionamento foi feita a partir da análise do HC 126.292 e confirmada nas ações declaratórias de constitucionalidade 43 e 44; 2) modificação das sanções decorrentes do impeachment

5 Esse raciocínio pode ser extraído de decisão do ministro Celso de Mello, o qual afirma que "[...] embora resida, primariamente, nos Poderes Legislativo e Executivo, a prerrogativa de formular e executar políticas públicas, revela-se possível, no entanto, ao Poder Judiciário, determinar, ainda que em bases excepcionais, especialmente nas hipóteses de políticas públicas definidas pela própria Constituição, sejam estas implementadas pelos órgãos estatais inadimplentes, cuja omissão - por importar em descumprimento dos encargos político-jurídicos que sobre eles incidem em caráter mandatório - mostra-se apta a comprometer a eficácia e a integridade de direitos sociais e culturais impregnados de estatura constitucional." (BRASIL, 2006, p. 1530, grifo nosso).

6 A título de instigação: no site da Câmara dos Deputados, é reconhecido que dos 380 (trezentos e oitenta) dispositivos passíveis de regulamentação, 117 (cento e dezessete) ainda não foram regulamentados. Desse número, 28 (vinte e oito) ainda não tiveram proposição (BRASIL, 2017a).

7 Relevante a defesa da importância da função legislativa feita por Humberto Ávila, o qual conclui que, "Se verdadeiras as conclusões no sentido de que os seus fundamentos [do neoconstitucionalismo] não encontram referibilidade no ordenamento jurídico brasileiro, defendê-lo, direta ou indiretamente, é cair numa invencível contradição performática: é defender a primazia da Constituição, violando-a. O 'neoconstitucionalismo', baseado nas mudanças antes mencionadas, aplicado no Brasil, está mais para o que se poderia denominar, provocativamente, de uma espécie enrustida 'não constitucionalismo': um movimento ou uma ideologia que barulhentamente proclama a supervalorização da Constituição enquanto silenciosamente promove a sua desvalorização." (ÁVILA, 2009, p. 19).

8 Segundo o desembargador Rômulo Pizzolatti, ao analisar recurso contra decisão do corredor-regional da Justiça Federal da $4^{\circ}$ Região, o qual determinou o arquivamento da representação contra Sérgio Fernando Moro, afirmou em seu voto que "[...] impõe-se advertir que essas regras jurídicas [art. 35 da Lei Orgânica da Magistratura Nacional; arts. 12 e 25 do Código de Ética da Magistratura Nacional; arts. $8^{\circ}$ e $9^{\circ}$ da Lei 9.296/96; art. 17 da Resolução $\mathrm{CNJ} \mathrm{n}^{\circ} 59$ de 09 de setembro de 2008] só podem ser corretamente interpretadas à luz dos fatos a que se ligam e de todo modo verificado que incidiram dentro do âmbito de normalidade por elas abrangido. É que a norma jurídica incide no plano da normalidade, não se aplicando a situações excepcionais, como bem explica o jurista Eros Roberto Grau. [...] Assim, tendo o levantamento do sigilo das comunicações telefônicas de investigados na referida operação servido para preservá-la das sucessivas e notórias tentativas de obstrução, por parte daqueles, garantindo-se assim a futura aplicação da lei penal, é correto entender que o sigilo das comunicações telefônicas (Constituição, art. $5^{\circ}$, XII) pode, em casos excepcionais, ser suplantado pelo interesse geral na administração da justiça e na aplicação da lei penal. A ameaça permanente à continuidade das investigações da Operação Lava-Jato, inclusive mediante sugestões de alterações na legislação, constitui, sem dúvida, uma situação inédita, a merecer um tratamento excepcional." (BRASIL, 2016b, online).

9 No original: "In the center of the counter-revolution stood the judiciary. [...] Law is perhaps the most pernicious of all weapons in political struggles, precisely because of the halo that surrounds the concepts of right and justice." (NEUMANN, 2009, p. 20.) 
10 Com o intuito de contextualizar essa atuação paradoxal, dois casos podem ser ressaltados: o primeiro é referente aos mandados de segurança 34.070 e 34.071, julgados monocraticamente pelo ministro Gilmar Mendes(,) no dia 18 de março de 2016, em que determinou a suspensão da "[...] eficácia da nomeação de Luiz Inácio Lula da Silva para o cargo de Ministro Chefe da Casa Civil", porquanto a "[...] conduta [nomeação de Lula] demonstra não apenas os elementos objetivos do desvio de finalidade, mas também a intenção de fraudar". Percebe-se que o Supremo Tribunal Federal, por meio da decisão de um de seus ministros mais antigos, posicionou-se no sentido de que a nomeação de um ministro de Estado pode ser barrada na situação de haver desvio de finalidade, já que atinge a moralidade administrativa, sendo tal decisão, aprioristicamente, correta; todavia, a lógica da referida decisão não foi mantida em caso similar. No dia 3 de fevereiro de 2017, o Presidente da República, Michel Temer, elevou o cargo de Moreira Franco ao status de Ministro de Estado. Deve, entretanto, ficar ressalvado que essa medida, que possibilitou que este gozasse do foro de prerrogativa de função, foi feita logo depois de o nome de Moreira Franco ser citado diversas vezes em um acordo de colaboração premiada. Em razão disso, a Rede de Sustentabilidade, utilizando-se dos mesmos argumentos que impediram que Lula fosse nomeado Ministro da Casa Civil (desvio de finalidade), ingressou com mandado de segurança no Supremo Tribunal Federal, solicitando que o ato do Presidente da República não tivesse efeito. O ministro Celso de Mello, responsável por analisar referida ação, contudo, indeferiu os pedidos realizados, pois não visualizou, diferentemente de seu colega de Corte, elementos que demonstrassem desvio de finalidade, bem como a nomeação a cargo que concede foro privilegiado não cria obstáculos capazes de macular uma ação penal.

11 "Exemplos de segunda espécie [ausência de identidade nas suas decisões], os tem fornecido o próprio Supremo Tribunal Federal, na contradição patente de vários julgados, - ficando, portanto, sem saber qual seja a verdadeira interpretação final da Constituição, relativamente a quaisquer outros casos ocorrentes da mesma natureza $[\ldots]$.

De certo, não querendo alongar-nos sobre os feitos diversos, em que assim se tem dado infelizmente, basta lembrar as suas decisões, manifestamente incongruentes, a respeito de duas questões de máxima importância, - os impostos interestaduais, e o estado de sítio." (CAVALCANTI, 1983, p. 313).

12 "Casos idênticos ou semelhantes são julgados de forma absolutamente disparatada no que tange ao critério normativo adotado pelos Magistrados. A prática jurisdicional brasileira enraizou uma convivência sem embargos a decisões distintas sobre situações análogas. Muito embora isso traga incoerência ao sistema, este parece estar mais compromissado com a discricionariedade judicial, adotando o critério (positivista) de aplicação por subsunção das leis, sem contar a proliferação de respostas contraditórias para situações idênticas com fulcro irrefletido na liberdade de interpretar as leis bem típica do modelo da civil law." (CUNHA; REIS, 2014, p. 263).

13 É crescente o número de obras que tratam a importância dos precedentes. Para maior aprofundamento, ver: (PEIXOTO, 2016; MACÊDO, 2017; LOPES FILHO, 2012, 2016).

14 Como apresentado por Ivar Hartmann e Lívia Ferreira, as decisões monocráticas passaram a ser a regra no Supremo Tribunal Federal, o que permite uma séria instabilidade e, consequentemente, uma insegurança jurídica, pois o êxito no processo dependerá do relator, que pode chegar a desrespeitar decisões proferidas pelo plenário da Corte (HARTMANN; FERREIRA, 2015).

15 "Que, até o julgamento definitivo desta ADPF, seja reconhecida, em caráter provisório, a impossibilidade de que pessoas que respondem ou venham a responder a ação penal instaurada pelo STF assumam ou ocupem cargos em cujas atribuições constitucionais figure a substituição do(a) Presidente da República.” (BRASIL, 2016a, online, grifo do autor).

16 Tais fatos estão expostos no relatório da decisão liminar proferida pelo ministro Marco Aurélio (BRASIL, 2016c, p. 2).

17 Art. 77. A eleição do Presidente e do Vice-Presidente da República realizar-se-á, simultaneamente, no primeiro domingo de outubro, em primeiro turno, e no último domingo de outubro, em segundo turno, se houver, do ano anterior ao do término do mandato presidencial vigente. $§ 1^{\circ}$ A eleição do Presidente da República importará a do Vice-Presidente com ele registrado. $§ 2^{\circ}$ Será considerado eleito Presidente o candidato que, registrado por partido político, obtiver a maioria absoluta de votos, não computados os em branco e os nulos. $\S 3^{\circ}$ Se nenhum candidato alcançar maioria absoluta na primeira votação, far-se-á nova eleição em até vinte dias após a proclamação do resultado, concorrendo os dois candidatos mais votados e considerando-se eleito 
aquele que obtiver a maioria dos votos válidos. $\S 4^{\circ} \mathrm{Se}$, antes de realizado o segundo turno, ocorrer morte, desistência ou impedimento legal de candidato, convocar-se-á, dentre os remanescentes, o de maior votação. $\S 5^{\circ} \mathrm{Se}$, na hipótese dos parágrafos anteriores, remanescer, em segundo lugar, mais de um candidato com a mesma votação, qualificar-se-á o mais idoso (BRASIL, 1988).

18 Deve-se frisar que a Constituição Federal veda a possibilidade de o Presidente da República ser responsabilizado por atos estranhos ao exercício de suas funções; contudo, gera-se a dúvida em relação à possibilidade de ele ser investigado nessa hipótese. Por isso, o Partido Democrático Trabalhista (PDT) ingressou com ação direta de inconstitucionalidade (ADI 5071), cuja relatoria é do ministro Luiz Fux, a fim de que o Supremo Tribunal Federal decida pela possibilidade de o Presidente da República ser investigado pela prática de infrações penais, ainda que tais atos sejam estranhos ao cargo (BRASIL, 2017c).

19 Deve ser deixado claro que, conquanto a LC 64 não preveja situações em que uma pessoa pode ser impedida de se candidatar ao cargo de Presidente da República por ter sido condenada em processo criminal, ainda que sua condenação não tenha sido confirmada em segunda instância, deve-se salientar que referida legislação eleitoral dispõe hipóteses de inelegibilidade sem decisões judiciais transitadas em julgado, cuja constitucionalidade é discutida pela doutrina, conforme destaca Néviton Guedes, o qual afirma que "[...] é digno de nota o fato de que a Lei Complementar 135/10, ao conferir nova redação à Lei Complementar 64/90, previu vários casos de inelegibilidades decorrentes de decisões judiciais não transitadas em julgado. Mais do que isso, a nova lei prevê casos de inelegibilidades decorrentes até mesmo de meras decisões administrativas. Precisamente por isso, como se viu, são muitas as vozes que questionam a constitucionalidade de imposição de restrições tão graves à capacidade política passiva, sobretudo, quando não impostas por decisões judiciais com trânsito em julgado." (GUEDES, 2013, p. 683).

20 Lopes Júnior (2016, p. 34), ao analisar o caráter instrumental do processo penal, afirma que "[...] o processo não pode mais ser visto como um simples instrumento a serviço do poder punitivo (direito penal), senão que desempenha o papel de limitador do poder e garantidor do indivíduo a ele submetido. Há que se compreender que o respeito às garantias fundamentais não se confunde com impunidade, e jamais se defendeu isso. $\mathrm{O}$ processo penal é um caminho necessário para chegar-se, legitimamente à pena. Daí por que somente se admite sua existência quando ao longo desse caminho forem rigorosamente observadas as regras e garantias constitucionalmente asseguradas (as regras do devido processo legal)".

21 Deve-se deixar registrado que, desde 2016, com a análise do HC 126.292/SP, o STF passou a haver o entendimento de que é possível, no âmbito processual penal, a execução antecipada da pena, ainda que não haja trânsito em julgado de sentença penal condenatória.

22 Segundo Jorge Reis Novais, em relação à possibilidade de prever todos os resultados de conflitos entre princípios, afirma que "[...] mesmo que fosse tecnicamente possível elaborar uma tal lista interminável, ela teria de ser feita ou pelo legislador ou pelo poder judicial. No primeiro caso, enquanto decisão ordinária, ela poderia ser revogada, alterada ou simplesmente derrogada pelo mesmo legislador democrático no quadro das ponderações pontuais a que procedesse. No segundo caso, não se vê por que razão deveriam os diferentes poderes constituídos, nas suas funções constitucionais de promoção dos fins do Estado, ficar vinculadamente condicionados por uma ordenação que, feita com um grau mínimo praticável de abstracção, é tão contestável, contingente e subjectiva como qualquer outra" (NOVAIS, 2010, p. 705).

23 Apesar de a aplicação da sanção penal, segundo a Constituição Federal, só ser possível com o trânsito em julgado de sentença penal condenatória, é imprescindível mencionar que a legislação prevê prisões de natureza cautelar, quais sejam, flagrante (art. 301, CPP), preventiva (art. 311, CPP) e temporária (Lei no 7.960/89).

24 Manifestações emotivas para fundamentar posições judiciais acham-se presentes, como nas pp. 1786 do inteiro teor do acórdão da Ação Penal n ${ }^{\circ} 470$, perante o STF e que restou conhecida como "julgamento do mensalão": "Nesta Casa, sou uma juíza brasileira, não uma juíza mineira, se bem que teria toda honra de ser de Minas apenas servidora. Tenho gosto em ser de Minas. Sou Minas como os mineiros todos são. Por isso, porque Minas não tem deixado de cumprir e honrar o seu compromisso com o Brasil nas horas mais difíceis; porque Minas merece ser lembrada, como é, historicamente por ter germinado de Tiradentes a Drummond, de Claudio Manoel da Costa a Bilac Pinto, por ter acolhido Milton Campos e Guimarães Rosa, Otto Lara Rezende e Paulo Mendes Campos, por cantar ainda hoje com Milton Nascimento querer toda gente feliz e que a justiça reine em meu 
País; porque sou cidadã a partir das Minas, vejo-me na contingência de, a partir desta Cadeira comprometida com a Justiça democrática, que não se faz sem respeito aos valores éticos, ter de realçar que o de que aqui se cuida não é de prática de um Estado, mas de gravame ao País, de condutas contra o Estado do Brasil" (voto Min. Cármen Lúcia) (BRASIL, 2013, online).

25 Ao tempo em que tomaria posse como Presidente do Tribunal Superior Eleitoral, antes do julgamento no STF, o ministro Marco Aurélio registrou em seu voto na Ação Penal n ${ }^{\circ} 470$, com base em sua visão "cristã", ter enviado "recado" ao então Presidente da República, Luis Inácio Lula da Silva, de que não seria interessante sua presença na solenidade (BRASIL, 2013, p. 1675), "[...] porque preciso, no discurso de posse, dar um recado. Qual foi o recado, Presidente, vou tomar um pouco mais o tempo do Colegiado, o que não fiz quanto às fatias anteriores, porque julgo que estamos no fecho da apreciação desta Ação Penal n ${ }^{\circ} 470$. Lancei, Presidente, reconheço que lancei, com desassombro: Infelizmente, vivenciamos tempos muito estranhos, em que se tornou lugar-comum falar dos descalabros que, envolvendo a vida pública, infiltraram na população brasileira - composta, na maior parte, de gente ordeira e honesta - um misto de revolta, desprezo e até mesmo repugnância. São tantas e tão deslavadas as mentiras, tão grosseiras as justificativas, tão grande a falta de escrúpulos que já não se pode cogitar somente de uma crise de valores, senão de um fosso moral e ético que parece dividir o País em dois segmentos estanques - o da corrupção, seduzido pelo projeto de alcançar o poder de uma forma ilimitada e duradoura, e o da grande massa comandada que, apesar do mau exemplo, esforça-se para sobreviver e progredir".

\section{REFERÊNCIAS}

ÁVILA, Humberto. "Neoconstitucionalismo": entre a "ciência do Direito" e o "Direito da Ciência”. Revista Eletrônica de Direito do Estado (REDE), Salvador, n. 17, p. 1-19, jan./mar. 2009. Disponível em: <http://www.direitodoestado.com/revista/rede-17-janeiro-2009-humberto\%20avila.pdf>. Acesso em: 20 nov. 2017.

BARRY, Brian. Justice as Impartiality. New York: Oxford University Press, 1996.

BRASIL. Câmara dos Deputados. Constituição Federal: dispositivos constitucionais sujeitos à regulamentação. Disponível em: <http://www.camara.leg.br/internet/infdoc/novoconteudo/html/leginfra/LeginfraNao.htm>. Acesso em: 15 maio 2017.

. Constituição da República Federativa do Brasil de 1988. Presidência da República, Brasília, DF, 1988. Disponível em: < http://www.planalto.gov.br/ccivil_03/constituicao/constituicao.htm>. Acesso em: 15 maio 2017.

. Supremo Tribunal Federal. RE 410.715 - AgR / SP. Relator: Min. Celso de Mello. São Paulo, 22 nov. 2005. Diário de Justiça, 3 fev. 2006. Disponível em: <http:// redir.stf.jus.br/paginadorpub/paginador.jsp?docTP $=\mathrm{AC} \& \operatorname{doc} \mathrm{ID}=354801>$. Acesso em: 10 fev. 2017.

. Supremo Tribunal Federal. AP 470. Acórdão. STF, Brasília, 2013. Disponível em: <ftp://ftp.stf.jus.br/ap470/InteiroTeor_AP470.pdf>. Acesso em 18. mar. 2017.

. Supremo Tribunal Federal. ADPF 402. Petição inicial. Redir, Brasília, 2016a, p. 20. Disponível em: <http://redir.stf.jus.br/estfvisualizadorpub/jsp/consultarprocessoeletronico/ ConsultarProcessoEletronico.jsf?seqobjetoincidente $=4975492>$. Acesso em 18. mar. 2017. 
. Tribunal Regional Federal (4. Região). [Recurso contra decisão do Corregedor-Regional da Justiça Federal da 4 Região]. Relator: Rômulo Pizzolatti. Consultor Jurídico, São Paulo, 2016b. Disponível em: <https:/www.conjur.com.br/dl/lava-jato-nao-seguir-regras-casos.pdf>. Acesso em: 18 mar. 2018.

. Supremo Tribunal Federal. ADPF 402. Medida Cautelar na Arguição de Descumprimento de Preceito Fundamental 402. Voto do Ministro Marco Aurélio. Redir, Brasília, 2016c, p. 2. Disponível em: < http://redir.stf.jus.br/estfvisualizadorpub/jsp/consultarprocessoeletronico/ConsultarProcessoEletronico.jsf?seqobjetoincidente $=4975492>$. Acesso em 18. mar. 2017.

. Supremo Tribunal Federal. ADPF 402. Referendo na Medida Cautelar na Arguição de Descumprimento de Preceito Fundamental 402. Voto do Ministro Celso de Mello. Redir, Brasília, 2016d, p. 11. Disponível em: < http://redir.stf.jus.br/estfvisualizadorpub/jsp/consultarprocessoeletronico/ConsultarProcessoEletronico.jsf?seqobjetoinciden te $=4975492>$. Acesso em 18. mar. 2017.

. Supremo Tribunal Federal. Ação Cautelar no 4.070, de 4 de maio de 2017. Relator: Ministro Teori Zavascki. Portal EBC, Brasília, 2017b. Disponível em: < http://www. ebc.com.br/sites/_portalebc2014/files/atoms/files/ac4070.pdf>. Acesso em: 20 jan. 2017.

. Supremo Tribunal Federal. Debates. Diário de Justiça Eletrônico, 11 nov. 2008. Disponível em: <http:/www.stf.jus.br/arquivo/cms/jurisprudenciaSumulaVinculante/anexo/SUV_11_12_13__Debates.pdf $>$. Acesso em: 20 jan. 2017.

. Supremo Tribunal Federal. ADI 5.701. Relator: Min. Luiz Fux. Pendente de julgamento. Redir, Brasília, 10 maio 2017c. Disponível em: < http://redir.stf.jus.br/estfvisualizadorpub/jsp/consultarprocessoeletronico/ConsultarProcessoEletronico.jsf?seqobjetoincid ente $=5184936>$. Acesso em: 5 jun. 2017.

CAVALCANTI, Amaro. Regime Federativo e a República Brasileira. Brasília: Universidade de Brasília, 1983.

CHAUÍ, Marilena. A Nervura do Real. São Paulo: Cia das Letras, 2000.

. Política em Espinosa. São Paulo: Cia. das Letras, 2003.

CUNHA, Guilherme Cardoso Antunes da; REIS, Maurício Martins. Por uma teoria dos precedentes obrigatórios confirmada dialeticamente ao controle concreto de constitucionalidade. Revista de Processo, São Paulo, v. 235, p. 263-292, set. 2014.

ESPINOSA, Baruch de. Tratado Teológico-Político. São Paulo: Martins Fontes, 2003.

. Tratado Político. São Paulo: Martins Fontes, 2009.

Editora, 2012. 
GUEDES, Néviton. Comentário ao art. 14, § 9. In: CANOTILHO, José Joaquim Gomes et al. (Coord.). Comentários à Constituição do Brasil. São Paulo: Saraiva, 2013.

GUIMARAENS, Francisco. Direito, Ética e Política em Spinoza. Rio de Janeiro: Lumen Juris, 2010.

HARTMANN, Ivar Alberto Martins; FERREIRA, Lívia da Silva. Ao relator, tudo: o impacto do aumento do poder do ministro relator no Supremo. Revista Opinião Jurídica, Fortaleza, v. 13, n. 17, p. 268-283, jan./dez. 2015. Disponível em: < http://periodicos.unichristus.edu.br/index.php/opiniaojuridica/article/view/266/179>. Acesso em: 30 nov. 2016.

ISRAEL, Jonathan I. Iluminismo Radical. São Paulo: Madras, 2009.

LIMA, Martonio Mont'Alverne Barreto; QUEIROZ, Paulo Roberto Clementino; CAR$\mathrm{MO}$, Valter Moura do. A ideologia como determinante da hermenêutica jurídica. Revista de Estudos Constitucionais, Hermenêutica e Teoria do Direito, São Leopoldo, v. 8, n. 2, p. 151-163, 2016. Disponível em: <http://www.revistas.unisinos.br/index.php/RECHTD/ article/view/rechtd.2016.82.03/5554>. Acesso em: 20 jun. 2017.

LISTA Fachin Odebrect. Consultor Jurídico, São Paulo, 11 abr. 2017. Disponível em: <http://s.conjur.com.br/dl/lista-fachin-odebrecht.pdf>. Acesso em: 5 jun. 2017.

LOPES FILHO, Juraci Mourão. Os precedentes judiciais no Constitucionalismo Brasileiro Contemporâneo. 2. ed. Salvador: JusPodivm, 2016.

. Precedente e norma: usam-se precedentes judiciais como se aplicam normas legislativas? Revista Opinião Jurídica, Fortaleza, v. 10, n. 14, p. 231-252, jan./dez. 2012. Disponível em: <http://periodicos.unichristus.edu.br/index.php/opiniaojuridica/article/ view/814/284>. Acesso em: 6 nov. 2017.

LOPES JÚNIOR. Aury. Fundamentos do Processo Penal: introdução crítica. 2. ed. São Paulo: Saraiva, 2016.

MACÊDO, Lucas Buril de. Precedentes judiciais e o direito processual civil. 2. ed. Salvador: JusPodivm, 2017.

MENDES, Gilmar Ferreira; VALE, André Rufino do. Comentário ao art. 5º, II. In: CANOTILHO, José Joaquim Gomes et al. (Coord.). Comentários à Constituição do Brasil. São Paulo: Saraiva, 2013.

MÜLLER, Friedrich. Teoria Estruturante do Direito. São Paulo: Revista dos Tribunais, 2009.

MÜLLER, Friedrich u. Ralph Christensen. Juristische Methodik. 2. Auflage. Berlin: Duncker \& Humblot, 2007.

NEUMANN, Franz. Behemot: the structure and practice of nacional socialism, 19331944. Chicago: Ivan R. Dee, 2009. 
NOVAIS, Jorge Reis. As Restrições aos Direitos Fundamentais não Expressamente Autorizadas pela Constituição. 2. ed. Coimbra: Coimbra Editora, 2010.

PEIXOTO, Ravi. Superação do precedente e segurança jurídica. 2. ed. Salvador: JusPodivm, 2016.

SILVA, Virgílio Afonso da. Direitos fundamentais: conteúdo essencial, restrições e eficácia. 2. ed. São Paulo, Malheiros, 2011.

SPINOZA, Baruch de. Tractatus de Intellectus Emendatione. Darmstadt: Wissenchaftliiche Buchgesellschaft, 2008.

STRECK, Lenio Luiz. Verdade e Consenso. Constituição, Hermenêutica e Teorias Discursivas. São Paulo: Saraiva, 2012.

. Compreender Direito. São Paulo, Revista dos Tribunais, 2013. 